\title{
Compartmentalization of Vascular Endothelial Growth Factor to the Epithelial Surface of the Human Lung
}

\author{
Robert J. Kaner ${ }^{1}$ and Ronald G. Crystal ${ }^{1,2}$ \\ ${ }^{\mathrm{l} D i v i s i o n}$ of Pulmonary and Critical Care Medicine, Weill Medical College of Cornell University, New York, \\ NY, USA \\ ${ }^{2}$ Institute of Genetic Medicine, Weill Medical College of Cornell University, New York, NY, USA \\ Accepted December 20, 2000.
}

\begin{abstract}
Background: Based on assessment of mRNA expression, the lung is a major site of expression of the vascular endothelial growth factor (VEGF) gene, largely from type II alveolar epithelial cells. With the knowledge that VEGF can function to induce vascular leak, we hypothesized that to protect the lung from pulmonary edema, the VEGF produced in the lung must be compartmentalized from the pulmonary endothelium, and thus must be compartmentalized to the surface of the respiratory epithelium.

Material and Methods: To assess this hypothesis, we quantified the levels of VEGF in human respiratory epithelial lining fluid recovered by bronchoalveolar lavage from normal individuals.

Results: Strikingly, human respiratory epithelial lining fluid contains $11 \pm 5 \mathrm{ng} / \mathrm{mL}$ as quantified by ELISA, a
\end{abstract}

500 -fold greater concentration than plasma $(22 \pm 10 \mathrm{pg} / \mathrm{mL}$, $p<0.0005)$. Western analysis of BAL fluid proteins showed the major VEGF isoform in respiratory epithelial lining fluid is VEGF165.

Conclusions: With the knowledge that proteins of molecular mass like VEGF (34 to $46 \mathrm{kDa}$ ) slowly diffuse across the alveolar epithelium, it is likely that this high level "reservoir" of VEGF protein on the respiratory epithelial surface plays a role in normal lung endothelial biology. However, this compartmentalized VEGF reservoir may also be a "Damocles sword" poised to induce lung endothelial permeability in conditions of acute lung injury when the integrity of the alveolar epithelial barrier is breached.

\section{Introduction}

Vascular endothelial growth factor (VEGF; also referred to as VEGF-A or VEGF-1), a 34-46 kDa mediator produced by many different cell types, has been intensively studied for its role in blood vessel formation in embryogenesis and for its ability to induce angiogenesis in tissues of both ischemic and nonischemic adults (1-6). VEGF is also expressed by many tumor cells and is believed to play a critical role in the ability of tumors to generate an adequate blood supply (3). The role of VEGF in pathogenic angiogenesis has also been implicated in the generation of hemangiomas and in proliferative retinopathy $(3,5,7,8)$. Almost forgotten, however, is that one of the original functions discovered for VEGF was its ability to induce vascular leak, i.e., to enhance blood vessel permeability. Originally observed by Senger et al. (9), when VEGF is injected into the skin of guinea pigs, its permeability function is readily observed as the leak of high molecular weight molecules from the vasculature into the surrounding tissues $(1,9,10)$.

Address correspondence and reprints to: Dr. Robert J. Kaner, Weill Medical College of Cornell University, New York Presbyterian Hospital, 520 East 70th Street, ST 505, New York, NY 10021, USA. Phone: (212) 746-2258. Fax: (212) 746-8383. E-mail: geneticmedicine@mail.med.cornell.edu
It is well recognized that of all organs, the expression of the VEGF gene at the mRNA level is highest in the lung $(11,12)$. In situ studies have demonstrated that the major site of VEGF mRNA expression in the lung is in alveolar type II epithelial cells (13-16). Together, however, these observations do not seem consistent. The alveolar structures are very fragile and very sensitive to enhanced permeability of the alveolar vasculature (17). If the VEGF gene is highly expressed in the lung epithelium and VEGF protein levels in lung are commensurate with VEGF mRNA levels, either the alveolar endothelium does not exhibit vascular leak in response to VEGF or VEGF would have to be compartmentalized to the epithelial surface, where the high levels of VEGF would have to diffuse across the tight alveolar epithelial barrier to reach the pulmonary endothelium. Using adenovirus-mediated transfer of the VEGF165 cDNA, we have recently demonstrated that exposure of the alveolar endothelium to high levels of VEGF results in pulmonary edema, which suggests that VEGF can induce vascular permeability if sufficient amounts reach the pulmonary endothelium (18).

Based on these observations, we hypothesize that the high level of expression of the VEGF gene in pulmonary epithelium results in compartmentalization of VEGF protein on the epithelial surface of 
the lower respiratory tract. To test this hypothesis, we have quantified VEGF levels in epithelial lining fluid (ELF) of normal individuals, and compared these levels to the plasma levels in the same individuals. Remarkably, the data demonstrate that pulmonary ELF VEGF levels are 500-fold greater than plasma, i.e., large amounts of VEGF are compartmentalized to the respiratory epithelial surface, an observation that has significant implications in the physiology of the lung in health and disease.

\section{Methods \\ Bronchoalveolar Lavage}

Bronchoalveolar lavage (BAL) to recover epithelial lining fluid of the lower respiratory tract was carried out as previously described (19). After signing informed consent, normal human nonsmoking volunteers ( 6 males, 3 females; age $28 \pm 4$ yr) underwent bronchoscopy with lavage under protocols approved by the Institutional Review Boards of Rockefeller University Hospital and the Weill Medical College of Cornell University. Briefly, a bronchoscope was advanced to a wedged position and five successive $20-\mathrm{mL}$ aliquots of phosphate buffered saline, pH 7.4 (PBS), were instilled into each of three different sites for a total of $300 \mathrm{~mL}$. The fluid was immediately aspirated after each $20-\mathrm{mL}$ aliquot to minimize dwell time (20). The recovered fluid (average 62\%, $185 \mathrm{~mL} \pm 12 \%$ ) was filtered through gauze to remove debris, the cells were pelleted $(300 \times \mathrm{g}, 5 \mathrm{~min})$, and the supernatant was removed. The cell pellets were resuspended in RPMI 1640 (Life Technologies, Rockville, MD), and an aliquot was counted in a hemacytometer. Cell counts in BAL fluid were $(9 \pm 4)$ $\times 10^{4}$ cells $/ \mathrm{mL}$. Cytospin preparations were prepared and stained with Diff-Quik (Dade International, Miami, FL) and evaluated by light microscopy. BAL fluid differential counts were as follows: alveolar macrophages $94 \pm 3 \%$, lymphocytes $4 \pm 2 \%$, and neutrophils $1 \pm 1 \%$. To ensure no contamination with platelets, the supernatant was then further centrifuged in a microfuge $\left(23^{\circ} \mathrm{C}, 3 \mathrm{~min}\right)$, and the supernatant was aliquoted and frozen at $-20^{\circ} \mathrm{C}$ until analysis.

\section{Plasma}

Venous blood was collected from the same individuals undergoing lavage just prior to the lavage procedure. Based on the knowledge that platelets contain VEGF $(21,22)$, we collected the blood in glass tubes containing buffered $0.105 \mathrm{M} \mathrm{Na}$ citrate (Becton Dickinson, Franklin Lakes, NJ). The citrated blood was centrifuged at $500 \times \mathrm{g}$ for $30 \mathrm{~min}$, the supernatant removed, and further centrifuged in a microfuge $\left(23^{\circ} \mathrm{C}, 3 \mathrm{~min}\right)$. The resulting supernatant was aliquoted and frozen at $-20^{\circ} \mathrm{C}$ until analysis.

\section{VEGF Levels}

VEGF levels in lavage fluid and plasma were determined by ELISA (R\&D Systems, Minneapolis, MN).
The dilution of ELF with the PBS used for lavage was corrected by the urea method described by Rennard et al. (20). The urea concentration in lavage fluid and plasma was determined spectrophotometrically using a urea color reagent (Sigma, St. Louis, MO). The epithelial lining fluid concentration of VEGF was calculated by the formula: $\mathrm{VEGF}_{\mathrm{ELF}}=\mathrm{VEGF}_{\mathrm{BAL}}$ (Urea plasma $_{\text {Urea }}$ BAL $)$.

\section{Western Analysis}

To assess the isoform of VEGF in ELF, the BAL fluid was concentrated on Centriprep devices with a 10,000 MW cutoff (Millipore, Bedford, MA). Proteins were assessed by sodium dodecyl sulfatepolyacrylamide gel electrophoresis under reducing conditions on $12 \%$ gels. After the proteins were transferred to nitrocellulose membranes, Western blotting was performed with a primary goat anti-human affinity purified IgG polyclonal antibody, which recognizes all isoforms of human VEGF $(0.1 \mathrm{mg} / \mathrm{mL}$ used at 1:250 dilution; R\&D Systems). The secondary antibody was an affinity purified alkaline phosphatase-conjugated donkey anti-goat IgG $(0.6 \mathrm{mg} / \mathrm{mL}$ used at a 1:10,000 dilution; Jackson ImmunoResearch, West Grove, PA). The signal was amplified by luminol (New England Nuclear) and chemiluminescence was detected by a brief exposure on X-OMAT film (Kodak, Rochester, NY).

\section{Statistics}

Group averages were expressed as mean \pm SEM. Differences of group means were compared with the Mann-Whitney U test. Spearman's rank correlation coefficients $\mathrm{r}_{\sigma}$ was calculated to examine the relationship of plasma and ELF VEGF. These nonparametric statistics were calculated using Number Cruncher Statistical System (NCSS, Kaysville, UT). A $p$ value $<0.05$ was considered significant.

\section{Results and Discussion}

VEGF was easily measurable in bronchoalveolar lavage fluid of all eight normal individuals evaluated, with an average concentration in lavage fluid of $104 \pm 41 \mathrm{pg} / \mathrm{mL}$ (Figure 1). Western analysis of VEGF proteins from concentrated BAL fluid from an additional three individuals demonstrated a predominant band which co-migrated with a purified recombinant human VEGF165 protein standard, suggesting that the predominant VEGF isoform in ELF is VEGF165 (Figure 2). Plasma levels of VEGF averaged $22 \pm 10 \mathrm{pg} / \mathrm{mL}$ (Figure 3), comparable to those reported by others when the plasma is collected in citrate to avoid contamination by platelet VEGF $(21,22)$. Strikingly, when corrected for the dilution by the PBS used to collect the epithelial lining fluid, the levels of VEGF in respiratory ELF averaged $11,000 \pm 5000 \mathrm{pg} / \mathrm{mL}$ ELF, a level 500 -fold greater than that in plasma of the same individuals 


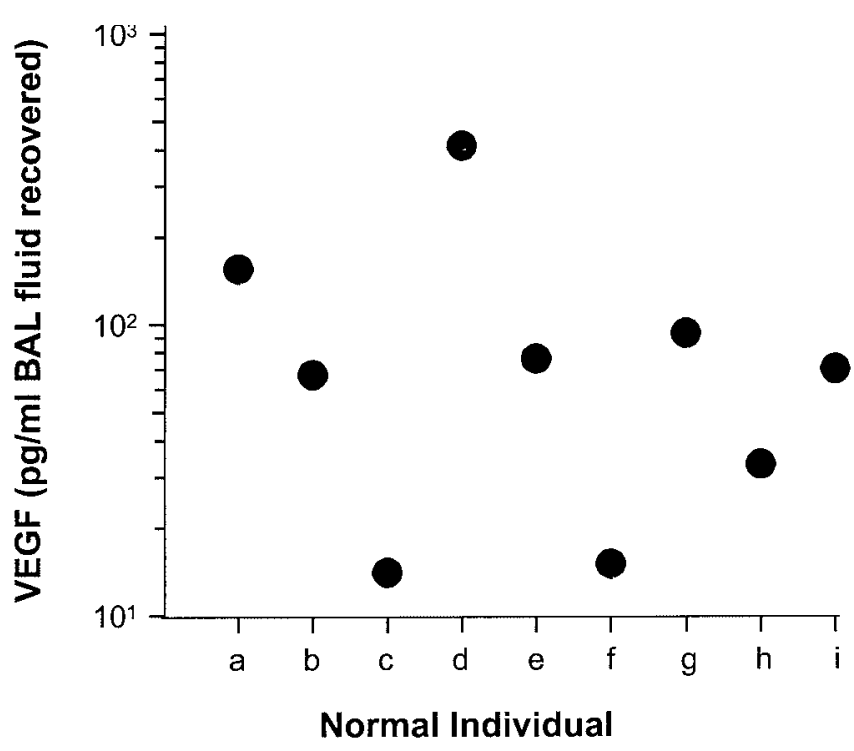

Fig. 1. VEGF levels in lavage fluid from normal individuals uncorrected for the dilution by the fluid used to recover the epithelial lining fluid. Lavage fluid was obtained and processed as in described in Methods. VEGF levels were quantified by ELISA. Each symbol represents the VEGF concentration from one BAL from a separate individual $(a-i)$.

$(p<0.0005)$. These data strongly suggest that local lung production of VEGF occurs and that the VEGF is compartmentalized on the respiratory epithelial surface. Consistent with this concept, there was no

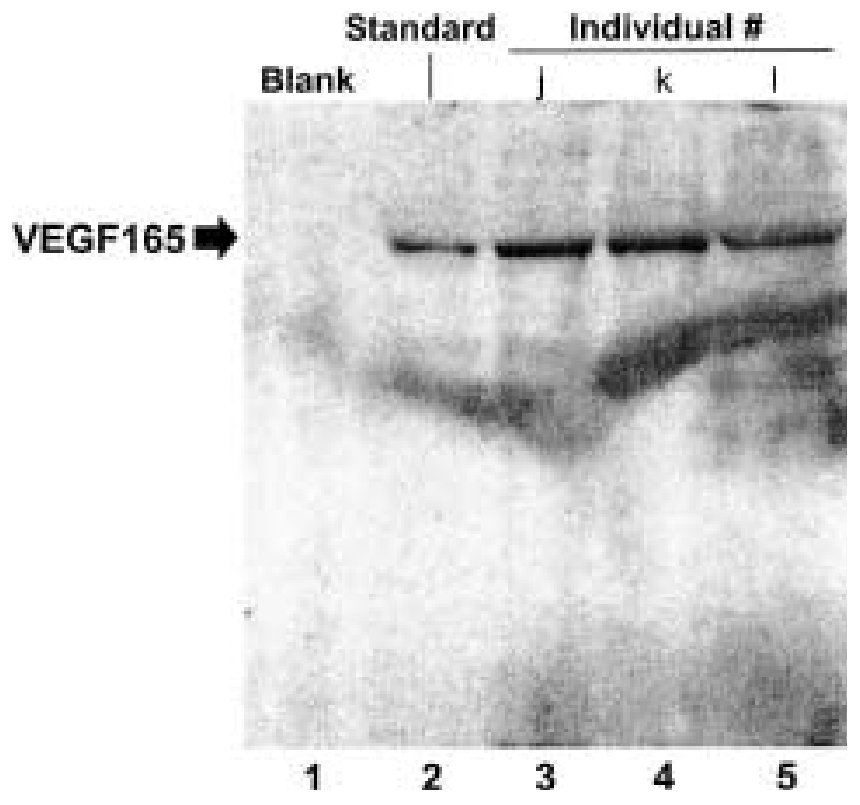

Fig. 2. Western analysis of VEGF in the lavage fluid. VEGF was detected with a primary affinity purified polyclonal donkey anti-human antibody that recognizes all of the VEGF isoforms. Lane 1: blank. Lane 2: recombinant human VEGF165 protein standard. Lanes 3-5: concentrated lavage fluid from three additional individuals not shown in Figure $1(\mathrm{j}, \mathrm{k}, \mathrm{l})$.

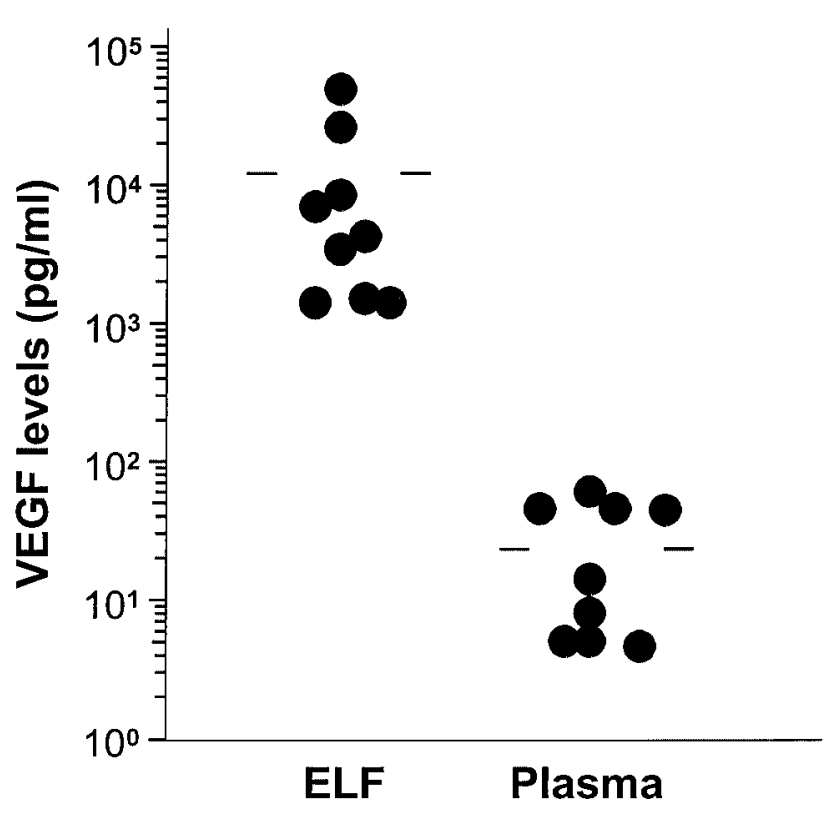

Fig. 3. VEGF levels in epithelial lining fluid and plasma of normal individuals. ELF VEGF levels were determined from the lavage fluid VEGF levels based on the dilution factor calculated from the levels of urea in lavage fluid and plasma. Horizontal bars indicate mean values for each group.

significant correlation among the ELF and plasma VEGF levels among the same individuals (Figure 4; $\left.\mathrm{r}_{\sigma}=0.46, p=0.19\right)$. It should be noted that sample size limitations do not preclude the possibility of

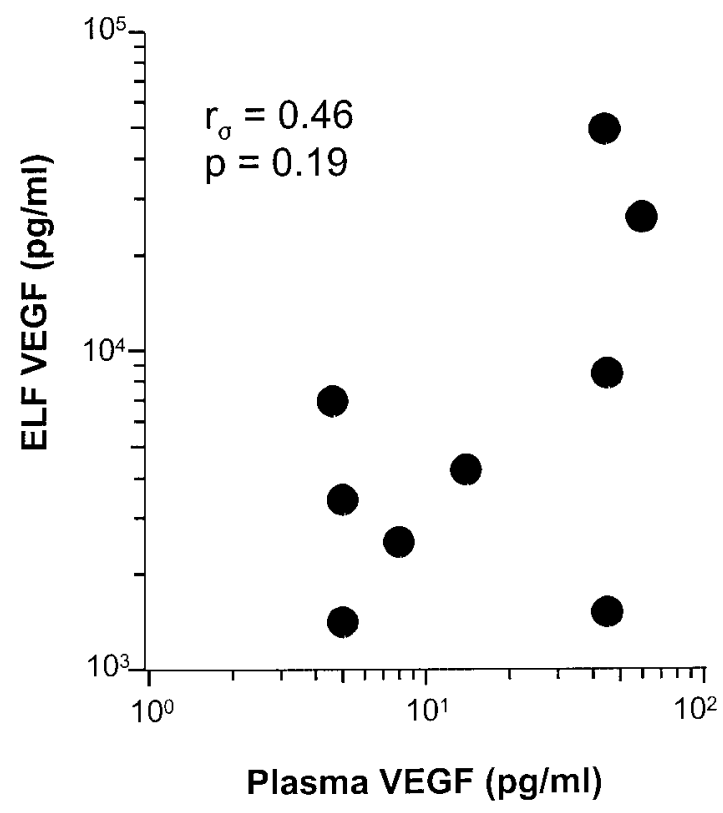

Fig. 4. Correlation of VEGF levels in epithelial lining fluid and plasma from the same individuals. The ELF VEGF values are on the ordinate and the plasma VEGF levels are on the abscissa. Linear correlation analysis demonstrated $\mathrm{r}_{\sigma}=0.46$, $p=0.19$. 
discovery of a correlation in specific patient age or sex subgroups as more individuals are evaluated.

\section{Vascular Endothelial Growth Factor}

The VEGF family includes structurally and functionally related polypeptides, designated VEGF-A through VEGF-E (23-25), of which VEGF-A (also called VEGF-1, but usually referred to as VEGF) is the prototypic member. VEGF is a heparin-binding glycoprotein, encoded by a $14 \mathrm{~kb}, 8$ exon gene. VEGF exists as five different species, each having $121,145,165,189$, or 206 amino acids, created by alternative splicing of the VEGF primary mRNA transcript of these; VEGF12 1 and 165 are the dominant forms expressed. VEGF typically exists as homodimers of these isoforms, but the existence of VEGF heterodimers has been described (26). VEGF was originally isolated from bovine pituitary tissue, but has been isolated from a variety of mammalian tissues, including cardiac myocytes and vascular smooth muscle cells. VEGF induces endothelial cell proliferation and directed migration, and promotes the formation of tube-like structures by endothelial cells cultured in collagen gels, reflective of its reported angiogenic potential in vivo (23-26). Although VEGF is primarily considered an angiogenic growth factor, it functions as a vascular permeability factor, and it can cause capillary leak, extravasation of fibrinogen, and the formation of a local fibrin lattice, which may serve as a template for endothelial growth and capillary formation (27).

VEGF is considered to be an endothelial cellspecific mitogen because of the localization of its two high-affinity, tyrosine kinase receptors, flt- 1 (fms-like-tyrosine kinase) and flk-1/KDR (fetal liver kinase/kinase domain region), to this cell type (flk-1 is the murine homologue of KDR) $(1,28)$. The importance of VEGF in normal development is highlighted by the observation that homozygous deletion of the flt-l or the flk-l genes or the heterozygous deletion of VEGF in knockout mice is lethal, with abnormal fetal development (28-30). Antibodies to VEGF negatively regulate VEGF function, and a murine anti-human monoclonal antibody has been shown to potently suppress angiogenesis and growth in a number of human tumor cell lines transplanted into nude mice and also to inhibit neovascularization in ischemic retinal disease $(31,32)$.

Extensive data have accumulated linking VEGF and VEGF receptor expression with both normal biological processes, such as embryonic development, growth and differentiation, and wound healing, and pathologic processes, such as neoplasia, rheumatoid arthritis, and proliferative retinopathies $(1-3,5,6)$. Hypoxic conditions in vitro and ischemia in vivo stimulate a transient increase in the expression of VEGF and its receptors flk-1 and flt- 1 that typically peaks within one week after the introduction of angiogenic stimuli $(14,26,33,34)$. This transcriptional upregulation appears to be regulated through a specific oxygen/heme protein response element in the VEGF gene (28). Finally, VEGF has been shown to induce the expression and/or secretion of a number of proteins, including interstitial collagenase, urokinase-type activator, and tissue-type plasminogen activator. These proteins are potentially important in modulating the extracellular matrix and supporting endothelial cell invasion and sprouting (35). Thus, the up-regulation of VEGF expression or the administration of VEGF may alone be sufficient to initiate and support angiogenesis. The critical native activity of this potent mediator, its relative endothelial selectivity (less selective mitogens such as FGF pose the potential risk of fibrosis and/or intimal hyperplasia), and the demonstrated ability of VEGF to induce angiogenesis in vivo have led to the use of VEGF as a therapeutic agent.

\section{VEGF and Normal Lung Physiology}

Consistent with our observations of high VEGF levels in adult ELF, increasing levels of VEGF as a function of time have been observed in tracheal aspirate fluid from preterm infants following delivery (36). Potential cellular sources of VEGF in the lung include alveolar epithelium (13-16), airway epithelium $(37,38)$, airway smooth muscle $(37,38)$, and neutrophils (39). The cells that are in direct contact with epithelial lining fluid are alveolar epithelium, alveolar macrophages, and to a much lesser extent, neutrophils, which normally comprise less than $1 \%$ of the mobile cells in the normal alveolus. Neutrophils produce VEGF when activated but little in the basal state $(13,39)$. Therefore, the most likely dominant cellular source of the VEGF observed in normal individuals is the alveolar epithelium. In situ hybridization studies of human fetal lung tissue and animal lungs suggest that type II alveolar epithelial cells are the major source of VEGF in the lung (13-16). In human fetal lung tissue, VEGF expression is concentrated at the basement membranes of type II cells; it has been hypothesized that VEGF acts at this location to direct the assembly of the pulmonary vasculature (15). It is likely that lung VEGF plays a role in normal maintenance and repair of the adult pulmonary circulation, where it is upregulated during recovery from hyperoxic injury in animal models (13).

The identification of the VEGF165 as the major isoform in epithelial lining fluid is not surprising because the 189 and 206 isoforms are primarily bound to the extracellular matrix and the lower molecular mass. In addition, lack of heparin-binding domain of VEGF121 likely allows VEGF 121 to diffuse more readily $(6,16,40-43)$. The molecular mass of VEGF165 is $19 \mathrm{kDa}$. Because VEGF165 forms homodimers, the VEGF165 on the respiratory epithelial surface has a molecular mass of $45 \mathrm{kDa}$ (including glycosylation). Although the movement of VEGF may be restricted by the heparin-binding domain in the molecule's C-terminal portion, the 
plasma molecule albumin with a molecular mass of $66 \mathrm{kDa}$ compartmentalizes between plasma and respiratory epithelial lining fluid with a partition coefficient of 0.09 (ELF to plasma) (20). Assuming the partition is similar for molecules with this mass compartmentalized to the epithelial surface of the lung, we would expect the ELF VEGF to serve as a reservoir with slow diffusion in the normal lung with the lung interstitium, slowly reaching the pulmonary endothelium. Precedent exists for locally produced protein to be highly concentrated in ELF relative to plasma. For example, Clara cell protein (CC16) a 16-17 kDa protein has been reported to be concentrated 5000-fold in rat ELF relative to plasma (44). Polarized secretion of VEGF from alveolar epithelium has not been studied; however, other types of epithelium do exhibit polarized apical $v s$ basal VEGF secretion $(45,46)$.

VEGF has important direct vasoactive effects $(47,48)$. In the pulmonary circulation, nitric oxide, a potent and short-lived locally acting mediator, is responsible for endothelium-dependent vasodilation (49). Nitric oxide production is determined by the activity of the enzyme endothelial nitric oxide synthase (eNOS), which produces NO by converting L-arginine to L-citrulline (50). Regulation of eNOS protein occurs at both the transcriptional and posttranscriptional levels $(51,52)$. Vascular endothelial growth factor up-regulates eNOS protein levels by several mechanisms $(51,52)$, in addition to inducing activation of eNOS by phosphorylation (50). Because VEGF is known to up-regulate eNOS, it is conceivable that VEGF may function locally in the lung to drive the continuous activation and/or expression of eNOS in the pulmonary endothelium, to maintain normal pulmonary circulatory homeostasis.

Although the expression of the flt-l and flk-1 (KDR) VEGF receptors is primarily restricted to endothelium, blood monocytes also express the VEGF receptor flt-1 (53) and respond to VEGF as a chemotactic factor (53). Therefore, another possible physiologic role for VEGF levels in ELF is to maintain a concentration gradient such that monocytes are continually recruited into the alveolar space from blood to replenish the pool of terminally differentiated alveolar macrophages. In this context, it is of interest that the levels of VEGF present in ELF far exceed the concentration of VEGF that is chemotactic for monocytes in the classic Boyden chamber assay (53).

\section{VEGF and Lung Pathophysiology}

In the context of the known function of VEGF as a permeability factor, the obvious pathophysiologic role of VEGF in the lung is to induce pulmonary edema. The 500-fold higher than plasma levels of VEGF in respiratory ELF may be a "Damocles sword," poised to induce pulmonary edema if the tight epithelial barrier is breached. Because adenovirusmediated gene transfer to the alveolar epithelium markedly expresses the transferred gene (54-56) and the alveolar epithelium genetically modified via an adenovirus vector results in both basolateral and apical secretion of the protein product of the transferred gene (57), it has been observed that, in a mouse gene transfer model, acute overexpression of VEGF in the lung epithelium causes noncardiogenic pulmonary edema (18). Because the alveolar epithelium normally represents a tight barrier to both fluid and macromolecular movement across it, the endothelium is likely to be protected from the high levels present in ELF. However, under conditions of acute injury to the alveolar epithelium, the epithelial barrier can be breached. In these circumstances, the alveolar endothelium would be directly exposed to the high levels of VEGF, which could secondarily contribute to an increase in endothelial permeability, a characteristic feature of acute lung injury. Interestingly, Beinert et al. $(58,59)$ have reported increased ELF VEGF in lung cancer patients undergoing radio-chemotherapy.

Although excess VEGF leads to pathological consequences, underexpression of VEGF also seems to have deleterious effects relevant to homeostasis of the pulmonary vasculature. These include an inadequate remodeling response to pulmonary hypertension (60) and the inability to respond appropriately to vasodilatory stimuli (61) (assuming VEGF controls eNOS). Recent data suggests that VEGF may be a necessary survival factor for endothelium (62). VEGF also has anti-apoptotic effects in endothelium $(63,64)$.

In summary, the present study demonstrates a remarkable compartmentalization of the potent VEGF molecule to the epithelial lining fluid of the lung. Although this likely serves a role in normal lung physiology as a reservoir for VEGF for the lung endothelium and possibly to recruit monocytes to the lung on a persistent basis, the high levels of VEGF on the respiratory epithelial surface also are a potential risk for the lung in that VEGF, if it reaches the alveolar endothelium in high levels, can induce pulmonary edema. In that context, one new approach for the treatment of acute, noncardiogenic pulmonary edema might be with strategies to inhibit VEGF, its receptors or downstream signal transduction pathways (18).

\section{Acknowledgments}

These studies were supported, in part, by M01RR00047 and M01RR00102, General Clinical Research Centers Program, NIH; the Will Rogers Memorial Fund, Los Angeles, CA; and GenVec, Inc., Gaithersburg MD. R. Kaner is supported, in part, by NIH K08-03089.

\section{References}

1. Dvorak HF, Brown LF, Detmar M, Dvorak AM. (1995) Vascular permeability factor/vascular endothelial growth factor, microvascular hyperpermeability, and angiogenesis. Am. J. Pathol. 146: 1029-1039. 
2. Ferrara N, Houck K, Jakeman L, Leung DW. (1992) Molecular and biological properties of the vascular endothelial growth factor family of proteins. Endocr. Rev. 13: 18-32.

3. Folkman J. (1995) Angiogenesis in cancer, vascular, rheumatoid and other disease. Nat. Med. 1: 27-31.

4. Ferrara N, Alitalo K. (1999) Clinical applications of angiogenic growth factors and their inhibitors. Nat. Med. 5: 1359-1364.

5. Ferrara N. (1999) Molecular and biological properties of vascular endothelial growth factor. J. Mol. Med. 77: 527-543.

6. Neufeld G, Cohen T, Gengrinovitch S, Poltorak Z. (1999) Vascular endothelial growth factor (VEGF) and its receptors. FASEB J. 13: 9-22.

7. Ozaki H, Seo MS, Ozaki K, Yamada H, Yamada E, Okamoto N, Hofmann F, Wood JM, Campochiaro PA. (2000) Blockade of vascular endothelial cell growth factor receptor signaling is sufficient to completely prevent retinal neovascularization. Am. J. Pathol. 156: 697-707.

8. Springer ML, Chen AS, Kraft PE, Bednarski M, Blau HM. (1998) VEGF gene delivery to muscle: potential role for vasculogenesis in adults. Mol. Cell 2: 549-558.

9. Senger DR, Galli SJ, Dvorak AM, Perruzzi CA, Harvey VS, Dvorak HF. (1983) Tumor cells secrete a vascular permeability factor that promotes accumulation of ascites fluid. Science 219: 983-985.

10. Dvorak HF, Nagy JA, Feng D, Brown LF, Dvorak AM. (1999) Vascular permeability factor/vascular endothelial growth factor and the significance of microvascular hyperpermeability in angiogenesis. Curr. Top. Microbiol. Immunol. 237: 97-132.

11. Monacci WT, Merrill MJ, Oldfield EH. (1993) Expression of vascular permeability factor/vascular endothelial growth factor in normal rat tissues. Am. J. Physiol. 264: C995-1002.

12. Berse B, Brown LF, Van de Water L, Dvorak HF, Senger DR. (1992) Vascular permeability factor (vascular endothelial growth factor) gene is expressed differentially in normal tissues, macrophages, and tumors. Mol. Biol. Cell 3: 211-220.

13. Maniscalco WM, Watkins RH, Finkelstein JN, Campbell MH. (1995) Vascular endothelial growth factor mRNA increases in alveolar epithelial cells during recovery from oxygen injury. Am. J. Respir. Cell Mol. Biol. 13: 377-386.

14. Tuder RM, Flook BE, Voelkel NF. (1995) Increased gene expression for VEGF and the VEGF receptors KDR/Flk and Flt in lungs exposed to acute or to chronic hypoxia. Modulation of gene expression by nitric oxide. J. Clin. Invest. 95: 1798-1807.

15. Bhatt AJ, Amin SB, Chess PR, Watkins RH, Maniscalco WM. (2000) Expression of vascular endothelial growth factor and Flk- 1 in developing and glucocorticoid-treated mouse lung. Pediatr. Res. 47: 606-613.

16. Zeng X, Wert SE, Federici R, Peters KG, Whitsett JA. (1998) VEGF enhances pulmonary vasculogenesis and disrupts lung morphogenesis in vivo. Dev. Dyn. 211: 215-227.

17. Bhattacharya J. (1998) Physiological basis of pulmonary edema. In Pulmonary Edema. MA Matthay and DH Ingbar, eds. Marcel Dekker: New York, 1-36.

18. Kaner RJ, Ladetto JV, Singh R, Fukuda N, Matthay MA, Crystal RG. (2000) Lung overexpression of the vascular endothelial growth factor gene induces pulmonary edema. Am. J. Respir. Cell Mol. Biol. 22: 657-664.

19. Russi TJ, Crystal RG. (1997) Bronchoalveolar lavage. In The Lung: Scientific Foundations. RG Crystal, JB West, ER Weibel, PJ Barnes, eds. Philadelphia: Lippincott-Raven, 371-382.

20. Rennard SI, Basset G, Lecossier D, O'Donnell KM, Pinkston P, Martin PG, Crystal RG. (1986) Estimation of volume of epithelial lining fluid recovered by lavage using urea as marker of dilution. J. Appl. Physiol. 60: 532-538.

21. Maloney JP, CC Silliman, DR Ambruso, J Wang, RM Tuder, NF Voelkel. (1998) In vitro release of vascular endothelial growth factor during platelet aggregation. Am. J. Physiol. 275: H1054-H1061.

22. Banks RE, Forbes MA, Kinsey SE, Stanley A, Ingham E, Walters C, Selby PJ. (1998) Release of the angiogenic cytokine vascular endothelial growth factor (VEGF) from platelets: significance for VEGF measurements and cancer biology. Br. J. Cancer 77: 956-964.

23. Birkenhager R, Schneppe B, Rockl W. (1996) Synthesis and physiological activity of heterodimers comprising different splice forms of vascular endothelial growth factor and placenta growth factor. Biochem. J. 316: 703-707.

24. Ferrara N, Henzel WJ. (1989) Pituitary follicular cells secrete a novel heparin-binding growth factor specific for vascular endothelial cells. Biochem. Biophys. Res. Commun. 161: 851-858.

25. Olofsson B, Pajusola K, Euler GV. (1996) Genomic organization of the mouse and human genes for vascular endothelial growth factor B (VEGF-B) and characterization of a second splice isoform. J. Biol. Chem. 271: 10310-10317.

26. Goto F, Goto K, Weindel K, Folkman J. (1993) Synergistic effects of vascular endothelial growth factor and basic fibroblast growth factor on the proliferation and cord formation of bovine capillary endothelial cells within collagen gels. Lab. Invest. 69: 50008-50017.

27. Muhlhauser J, Jones M, Yamada I, Cirielli C, Lemarchand P, Gloe TR, Bewig B, Signoretti S, Crystal RG, Capogrossi MC. (1996) Safety and efficacy of in vivo gene transfer into the porcine heart with replication-deficient, recombinant adenovirus vectors. Gene Ther. 3: 145-153.

28. Shibuya M, Yamaguchi S, Yamane A, Ikeda T, Tojo A, Matsushime H, Sato M. (1990) Nucleotide sequence and expression of a novel human receptor- type tyrosine kinase gene $(f t)$ closely related to the fms family. Oncogene 5: 519-524.

29. Gilgenkrantz H, Duboc D, Juillard V, Couton D, Pavirani A, Guillet JG, Briand P, Khan A. (1995) Transient expression of genes transferred in vivo into heart using first-generation adenoviral vectors: Role of the immune response. Hum. Gene Ther. 6: 1265-1274.

30. Fong GH, Rossant J, Gertsenstein M, Breitman ML. (1995) Role of the Flt- 1 receptor tyrosine kinase in regulating the assembly of vascular endothelium. Nature 376: 66-70.

31. Kong H-L and Crystal RG. (1998) Gene Therapy Strategies for Tumor Anti-angiogenesis. J. Natl. Cancer Inst. 90: 273-286.

32. Shalaby F, Rossant J, Yamaguchi TP, Gertsenstein M, Wu XF, Breitman ML, Schuh AC. (1995) Failure of blood-island formation and vasculogenesis in Flk-1-deficient mice. Nature 376: 62-66.

33. Waltenberger J, Mayr U, Pentz S. (1996) Functional upregulation of the vascular endothelial growth factor receptor KDR by hypoxia. Circulation 94: 1647-1654.

34. Park JE, Keller GA, Ferrara N. 1993 The vascular endothelial growth factor (VEGF) isoforms: differential deposition into the subepithelial extracellular matrix and bioactivity of extracellular matrix-bound VEGF. Mol. Biol. Cell 4: 1317-1326.

35. Pepper MS, Ferrara N, Orci L, Montesano R. 1991 Vascular endothelial growth factor (VEGF) induces plasminogen activator inhibitor-1 in microvascular endothelial cells. Biochem. Biophys. Res. Commun. 181: 902-906.

36. Lassus P, Ristimaki A, Ylikorkala O, Viinikka L, Andersson S. (1999) Vascular endothelial growth factor in human preterm lung. Am. J. Respir Crit. Care Med. 159: 1429-1433.

37. Christou H, Yoshida A, Arthur V, Morita T, Kourembanas S. (1998) Increased vascular endothelial growth factor production in the lungs of rats with hypoxia-induced pulmonary hypertension. Am. J. Respir. Cell Mol. Biol. 18: 768-776.

38. Fehrenbach $H$, Kasper $M$, Haase $M$, Schuh D, Muller $M$. (1999) Differential immunolocalization of VEGF in rat and human adult lung, and in experimental rat lung fibrosis: light, fluorescence, and electron microscopy. Anat. Rec. 254: 61-73.

39. Gaudry M, Bregerie O, Andrieu V, El Benna J, Pocidalo MA, Hakim J. (1997) Intracellular pool of vascular endothelial growth factor in human neutrophils. Blood 90: 4153-4161.

40. Klagsbrun M and D'Amore PA. 1996 Vascular endothelial growth factor and its receptors. Cytokine. $\theta$ Growth Factor. Reviews. 7: 259-270.

41. Cohen T, Gitay-Goren H, Sharon R, Shibuya M, Halaban R Levin BZ, Neufeld G. (1995) VEGF12 1, a vascular endothelial 
growth factor (VEGF) isoform lacking heparin binding ability, requires cell-surface heparan sulfates for efficient binding to the VEGF receptors of human melanoma cells. J. Biol. Chem. 270: 11322-11326.

42. Gitay-Goren H, Soker S, Vlodavsky I, Neufeld G. (1992) The binding of vascular endothelial growth factor to its receptors is dependent on cell surface-associated heparin-like molecules. J. Biol. Chem. 267: 6093-6098.

43. Gitay-Goren H, Cohen T, Tessler S, Soker S, Gengrinovitch S, Rockwell P, Klagsbrun M, Levi BZ, Neufeld G. (1996) Selective binding of VEGF12 1 to one of the three vascular endothelial growth factor receptors of vascular endothelial cells. J. Biol. Chem. 271: 5519-5523.

44. Halatek T, Hermans C, Broeckaert F, Wattiez R, Wiedig M, Toubeau G, Falmagne P, Bernard A. (1998) Quantification of Clara cell protein in rat and mouse biological fluids using a sensitive immunoassay. Eur. Respir. J. 11: 726-733.

45. Blaauwgeers HG, Holtkamp GM, Rutten H, Witmer AN, Koolwijk P, Partanen TA, Alitalo K, Kroon ME, Kijlstra A, H van, V, et al. (1999) Polarized vascular endothelial growth factor secretion by human retinal pigment epithelium and localization of vascular endothelial growth factor receptors on the inner choriocapillaris. Evidence for a trophic paracrine relation. Am. J. Pathol. 155: 421-428.

46. Hornung D, Lebovic DI, Shifren JL, Vigne JL, Taylor RN. (1998) Vectorial secretion of vascular endothelial growth factor by polarized human endometrial epithelial cells. Fertil. Steril. 69: 909-915.

47. Ku DD, Zaleski JK, Liu S, Brock TA. (1993) Vascular endothelial growth factor induces EDRF-dependent relaxation in coronary arteries. Am. J. Physiol. 265: H586-H592.

48. Murohara T, Horowitz JR, Silver M, Tsurumi Y, Chen D, Sullivan A, Isner JM. (1998) Vascular endothelial growth factor/vascular permeability factor enhances vascular permeability via nitric oxide and prostacyclin. Circulation 97: 99-107.

49. Fagan KA, Tyler RC, Sato K, Fouty BW, Morris KGJ, Huang PL, McMurtry IF, Rodman DM. (1999) Relative contributions of endothelial, inducible, and neuronal NOS to tone in the murine pulmonary circulation. Am. J. Physiol. 277: L472-L478.

50. McCabe TJ, Fulton D, Roman LJ, Sessa WC. (2000) Enhanced electron flux and reduced calmodulin dissociation may explain "calcium-independent" eNOS activation by phosphorylation. J. Biol. Chem 275: 6123-6128.

51. Bouloumie A, Schini-Kerth VB, Busse R. (1999) Vascular endothelial growth factor up-regulates nitric oxide synthase expression in endothelial cells. Cardiovasc. Res. 41: 773-780.

52. Shen BQ, Lee DY, Zioncheck TF. (1999) Vascular endothelial growth factor governs endothelial nitric-oxide synthase expression via a KDR/Flk-1 receptor and a protein kinase C signaling pathway. J. Biol. Chem. 274: 33057-33063.

53. Clauss $M$, Weich $H$, Breier $G$, Knies U, Rockl W, Waltenberger J, Risau W. (1996) The vascular endothelial growth factor receptor Flt-1 mediates biological activities. Implications for a functional role of placenta growth factor in monocyte activation and chemotaxis. J. Biol. Chem. 271: 17629-17634.
54. Mastrangeli A, Danel C, Rosenfeld MA, Stratford-Perricaudet L, Perricaudet M, Pavirani A, Lecocq JP, Crystal RG. (1993) Diversity of airway epithelial cell targets for in vivo recombinant adenovirus-mediated gene transfer. J. Clin. Invest. 91: 225-234.

55. Rosenfeld MA, Siegfried W, Yoshimura K, Yoneyama K, Fukayama M, Stier LE, Paakko PK, Gilardi P, StratfordPerricaudet LD, Perricaudet M, et al. (1991) Adenovirusmediated transfer of a recombinant alpha 1- antitrypsin gene to the lung epithelium in vivo. Science 252: 431-434.

56. Rosenfeld MA, Yoshimura K, Trapnell BC, Yoneyama K, Rosenthal ER, Dalemans W, Fukayama M, Bargon J, Stier LE, Stratford-Perricaudet L. (1992) In vivo transfer of the human cystic fibrosis transmembrane conductance regulator gene to the airway epithelium. Cell 68: 143-155.

57. Siegfried W, Rosenfeld M, Stier L, Stratford-Perricaudet L, Perricaudet M, Pavirani A, Lecocq J-P, Crystal RG. (1995) Polarity of secretion of $\alpha$ l-antitrypsin by human respiratory epithelial cells after adenoviral transfer of a human $\alpha 1$ - antitrypsin cDNA. Am. J. Respir. Cell Mol. Biol. 12: 379-384.

58. Beinert T, Binder D, Oehm C, Ziemer S, Priem F, Schweigert M, Stuschke M, Fleischhacker M, Siebert G, Mergenthaler HG, et al. (1999) Increased levels of vascular endothelial growth factor in bronchoalveolar lavage of patients with bronchial carcinoma effect of tumour activity and oxidative stress due to radio-chemotherapy? Eur. J. Med. Res. 4: 328-334.

59. Beinert T, Binder D, Oehm C, Ziemer S, Priem F, Stuschke $M$, Schweigert M, Siebert G, Mergenthaler HG, Schmid P, et al. (2000) Further evidence for oxidant-induced vascular endothelial growth factor up-regulation in the bronchoalveolar lavage fluid of lung cancer patients undergoing radiochemotherapy. J. Cancer Res. Clin. Oncol. 126: 352-356.

60. Partovian $C$, Adnot S, Eddahibi S, Teiger E, Levame M, Dreyfus P, Raffestin B, Frelin C. (1998) Heart and lung VEGF mRNA expression in rats with monocrotaline-or hypoxiainduced pulmonary hypertension. Am. J. Physiol. 275: H1948H1956.

61. Arcot SS, Lipke DW, Gillespie MN, Olson JW. (1993) Alterations of growth factor transcripts in rat lungs during development of monocrotaline-induced pulmonary hypertension. Biochem. Pharmacol. 46: 1086-1091.

62. Zachary I, Mathur A, Yla-Herttuala S, Martin J. (2000) Vascular protection : A novel nonangiogenic cardiovascular role for vascular endothelial growth factor. Arterioscler. Thromb. Vasc. Biol. 20: 1512-1520.

63. Gerber HP, Dixit V, Ferrara N. (1998) Vascular endothelial growth factor induces expression of the antiapoptotic proteins Bcl-2 and Al in vascular endothelial cells. J. Biol. Chem. 273: 13313-13316.

64. Spyridopoulos I, Brogi E, Kearney M, Sullivan AB, Cetrulo C, Isner JM, Losordo DW. (1997). Vascular endothelial growth factor inhibits endothelial cell apoptosis induced by tumor necrosis factor-alpha: balance between growth and death signals. J. Mol. Cell Cardiol. 29: 132 1-1330. 